\title{
PREVALENCE OF SARS-CoV-2 INFECTION AND RISK FACTORS IN HEALTH CARE WORKERS*
}

\section{CZESTOŚĆ ZAKAŻEŃ WIRUSEM SARS-CoV-2 ORAZ CZYNNIKI RYZYKA ZAKAŻENIA WŚRÓD PRACOWNIKÓW OCHRONY ZDROWIA*}

\author{
${ }^{1}$ Medical University of Silesia in Katowice, Doctoral School \\ Szkoła Doktorska Śląskiego Uniwersytetu Medycznego w Katowicach \\ ${ }^{2}$ Medical University of Silesia in Katowice, Faculty of Medical Sciences, Department of Epidemiology \\ Śląski Uniwersytet Medyczny,Wydział Nauk Medycznych w Katowicach, Katedra i Zakład Epidemiologii
}

\begin{abstract}
The COVID-19 pandemic verifies the preparation of medical care in individual countries in terms of the fluent of guaranteed medical services provided to the people in need. Due to the easy spread of SARS-CoV-2 virus when in direct contact with the patients, health care workers are at an increased risk of infection. Nurses and auxiliary staff, as well as medical doctors, were most frequently infected. The prevalence of infection depends on the adopted reporting method, including the diagnostic test used to recognize the infection, the nature of the work performed, but also on the gender, knowledge, and individual behavior of employees while performing their professional duties. It ranges from 5-30\% depending on the country and the occupational group, and the highest rates were recorded in the initial phase of the pandemic. A review of the literature shows the lack of a uniform, transparent system of reporting infections in health care workers, which makes a reliable assessment of the epidemiological situation in this area difficult.
\end{abstract}

Key words: SARS-CoV-2, COVID-19,Health care workers, health care personel

\section{STRESZCZENIE}

Pandemia COVID-19 weryfikuje stan przygotowania systemów opieki zdrowotnej w poszczególnych krajach w zakresie płynności gwarantowanych świadczeń medycznych udzielanych osobom potrzebującym. Z uwagi na łatwość rozprzestrzeniania się wirusa SARS-CoV-2 w bezpośrednim kontakcie z pacjentem, pracownicy medyczni znajdują się w grupie zwiększonego ryzyka zakażenia. Najczęściej zakażeniu ulegały pielęgniarki i personel pomocniczy, a także lekarze. Częstość rozpowszechnienia zakażeń zależy od przyjętego sposobu raportowania, w tym testu diagnostycznego stosowanego do rozpoznania zakażenia, od charakteru wykonywanej pracy, ale także od płci, wiedzy i indywidualnych zachowań pracowników przy pełnieniu obowiązków zawodowych. Kształtuje się w zakresie 5-30\% w zależności od kraju i grupy zawodowej, największe częstości odnotowywano w początkowej fazie pandemii. Przegląd piśmiennictwa wskazuje na brak jednolitego, przejrzystego systemu raportowania zakażeń u pracowników medycznych, co sprawia, że wiarygodna ocena sytuacji epidemiologicznej w tym zakresie jest utrudniona.

Slowa kluczowe: SARS-CoV-2, COVID-19, pracownicy medyczni

\footnotetext{
* The work was supported within the framework of the project „The prevalence, course, and risk factors of SARS-CoV-2 infection in the population of the Upper Silesian Agglomeration in 2020" (grant number 2020/ABM/COVID19/0044 from the Medical Research Agency, Poland)/

* Praca jest finansowana w ramach projektu „Rozpowszechnienie, przebieg i czynniki ryzyka zakażenia wirusem SARS-CoV-2 w populacji Aglomeracji Górnośląskiej w 2020 roku” ze środków Agencji Badań Medycznych, Projekt nr 2020/ABM/COVID19/0044.
}

(C) National Institute of Public Health - National Institute of Hygiene / Narodowy Instytut Zdrowia Publicznego - Państwowy Zakład Higieny 


\section{INTRODUCTION}

The COVID-19 pandemic has become a challenge to healthcare systems around the world and it tests their level of readiness to deliver fluent medical care in times of epidemic. The healthcare personnel constitutes the fundamental and indisposable part of the healthcare delivery, as without a sufficient number of doctors, nurses, or paramedics it would be impossible to provide safe, and effective care for patients suffering from COVID-19, as well as other life-threatening conditions. Due to the ease with which the virus spreads, medical workers are at an increased risk of infection when providing direct patient care. This risk is estimated to be 3.4 (hazard risk is 3.4) when compared to the general population of the USA and Great Britain, but it decreases threefold with the proper use of the recommended security measures when in contact with patients (1). At the beginning of April 2020, The World Health Organization (WHO) estimated that more than 20,000 healthcare professionals in 52 countries from within the WHO have contracted SARS-CoV-2. At the same time, potential factors were identified which, in connection with the exposure whilst performing the duties, increase the risk of infection. Above all, these include long working hours and accompanying fatigue, as well as failure to use the recommended personal protective equipment (PPE) (2). On May 8, 2020, The European Center for Disease Prevention and Control (ECDC), presented data on 15 European countries, which documented that on average one in four infected with SARS-CoV-2 is a healthcare worker $(23 \% ; 43,774$ / 188693), and the median was $14 \%$ (1-59\%) (3). As of May 6, 2020, the International Council of Nurses reported that the percentage of healthcare personnel among all COVID-19 cases out of the 30 researched countries is on average at the level of $6 \%(0-18 \%)$ (4).

\section{METHODOLOGY}

This work presents the most important observations resulting from the review of the available literature. The research papers available in the Medline database, PubMed, and Mendeley browsers published up to February 4, 2021, were analyzed. The following keywords were used to select the articles for analysis: SARS-CoV-2, COVID-19, health care workers, healthcare personnel. Aside from these, reports on the number of infected healthcare practitioners conducted by institutions such as the Robert Koch Institute in Berlin (Germany), the Istituto Superiore di Sanità in Rome (Italy), the Pan American Health Organization, and World Health Organization were also analyzed. The data on the situation in Poland came from the press releases provided by the Ministry of Health.

\section{WSTĘP}

Pandemia COVID-19 stała się wyzwaniem dla systemów opieki zdrowotnej na całym świecie.Najważniejszą częścią tych systemów pozostaje personel medyczny, bowiem bez wystarczającej liczby lekarzy, pielęgniarek czy ratowników medycznych nie można zapewnić płynnej, bezpiecznej i skutecznej opieki nad chorymi na COVID-19, a także na inne choroby stwarzające zagrożenia utraty życia. $Z$ uwagi na łatwość rozprzestrzeniania się wirusa $\mathrm{w}$ bezpośrednim kontakcie z pacjentem, pracownicy medyczni znajdują się $\mathrm{w}$ grupie zwiększonego ryzyka zakażenia. Ryzyko to ocenia się na poziomie $\mathrm{HR}=3,4$ (skorygowany wspótczynnik ryzyka) w porównaniu do populacji generalnej USA oraz Wielkiej Brytanii i warto dodać, że ryzyko to trzykrotnie maleje przy prawidłowym stosowaniu zalecanych zabezpieczeń w kontakcie z chorymi (1). $\mathrm{Na}$ początku kwietnia 2020r. Światowa Organizacja Zdrowia (WHO) oszacowała, że ponad 20000 osób wykonujących zawód medyczny na terenie 52 państw objętych działalnością WHO uległo zakażeniu wirusem SARS-CoV-2. Określono jednocześnie potencjalne czynniki, które w związku z wykonywaną pracą podnoszą ryzyko zakażenia. Są wśród nich przede wszystkim długie godziny pracy i towarzyszące im zmęczenie, a także niestosowanie zalecanych środków ochrony osobistej (2). Europejskie Centrum ds. Zapobiegania i Kontroli Chorób (ECDC) w dniu 8.05.2020 przedstawiło z kolei dane dotyczące 15 krajów europejskich, w których udokumentowano, że średnio co czwarty zakażony wirusem SARS-CoV-2 to pracownik opieki zdrowotnej $(23 \%$; 43774/188693), a mediana kształtowała się na poziomie 14\% (1-59\%) (3). Międzynarodowa Rada Pielęgniarek na dzień 6.05.2020 raportowała, że odsetek personelu medycznego wśród wszystkich chorych na COVID-19 zgłoszonych w 30 krajach kształtuje się średnio na poziomie 6\% (0-18\%) (4).

\section{METODOLOGIA}

W prezentowanej pracy przedstawiono najistotniejsze obserwacje wynikające z przeglądu dostępnego piśmiennictwa. Analizie poddano prace udostępnione w bazie Medline, przeglądarce PubMed oraz Mendeley opublikowane do 4.02.2021r. Przy wyborze prac do analizy wykorzystano następujące słowa kluczowe: SARS-CoV-2, COVID-19, health care workers, healthcare personel. Niezależnie od tego przeanalizowano również raporty poświęcone liczbie osób zakażonych, wykonujących zawody medyczne prowadzone przez instytucje takie jak Instytut Roberta Kocha w Berlinie (Niemcy), Istituto Superiore di Sanità w Rzymie (Włochy) oraz Pan American Health Organization, 


\section{REPORTING THE PREVALENCE OF SARS- COV-2 INFECTION AMONG HEALTHCARE PERSONNEL}

Each of the reports cited in this paper indicated that monitoring the situation regarding the number of SARS-CoV-2 infections among medical personnel is not an easy task and is accompanied by the lack of a uniform method of case reporting. Both WHO and the International Council of Nurses appealed to individual countries to systematically report cases of infections among the healthcare personnel $(4,5)$. Unfortunately, few countries responded to this challenge and as a consequence, there is little precise and, above all, systematic data on the epidemiological situation of SARS-CoV-2 amongst healthcare professionals. An example of a country, with a regularly updated register of infections among healthcare staff, is Ireland, as their weekly epidemiological reports include the exact number of infected workers. The reports of the Pan American Health Organization (PAHO) concerning the situation in the countries of the Americas also seem credible (6).

In Poland, the reporting status does not seem reliable, with the Supreme Medical Chamber appealing twice already to the Ministry of Health to implement a monitoring and reporting system for the number of infections among healthcare professionals in connection with COVID-19 (7). So far, the data on the number of SARS-CoV-2 infections among healthcare staff is published by the Polish Press Agency and come from the ICT system (EWP-Records of People Entering Poland), which is used by the doctors working within Primary Healthcare to issue orders for testing for the presence of the virus. The EWP system makes it possible to indicate the profession of a given patient for which the order for PCR testing is issued. With regards to the healthcare workers, the following categories were distinguished: medical doctors, nurses, paramedics, other healthcare workers. Next, the data on the course of infection comes from the National Register of Patients with COVID-19, and on this basis, information on the number of deaths among medical personnel is made available. Current data as of December 1, 2020, provided by the Ministry of Health indicate that a total of 40,669 nurses, 15,720 doctors, 2,487 paramedics, 3,754 midwives, 1,253 laboratory diagnosticians, 1,636 pharmacists, and 20 medical assistants have been infected since the beginning of the pandemic. However, there is no exact information on whether the list also includes cases from the beginning of the epidemic (March / April 2020), which is when the data on infections started being collected by the regional sanitary inspection. When it comes to the number of deaths, according to the data of the National Register
World Health Organization. Dane dotyczące Polski pochodziły $\mathrm{z}$ informacji prasowych podawanych przez Ministerstwo Zdrowia.

\section{RAPORTOWANIE ROZPOWSZECHNIENIA ZAKAŻEŃ WIRUSEM SARS-COV-2 WŚRÓD PERSONELU MEDYCZNEGO}

W każdym z cytowanych w pracy raportów wskazywano, że monitorowanie sytuacji dotyczącej liczby zakażeń SARS-CoV-2 wśród personelu medycznego nie jest zadaniem łatwym i towarzyszy mu brak jednolitego sposobu rejestracji. Zarówno WHO jak też Międzynarodowa Rada Pielęgniarek wystosowały apel do poszczególnych państw o systematyczne raportowanie przypadków zakażeń wśród personelu medycznego $(4,5)$. Niestety, niewiele krajów odpowiedziało na ten apel i w konsekwencji niewiele jest dokładnych, a przede wszystkim systematycznych danych monitoringowych na temat sytuacji epidemiologicznej SARS-CoV-2 u osób wykonujących zawody medyczne. Przykładem takiego kraju, w którym istnieje systematyczny rejestr przypadków zakażeń w ochronie zdrowia jest Irlandia, w cotygodniowych raportach epidemiologicznych podaje się dokładną liczbę zakażonych medyków. Wiarygodne wydają się również raporty Pan American Health Organization (PAHO), które dotyczą sytuacji w krajach obu Ameryk (6).

W Polsce sytuacja nie wygląda najlepiej, Naczelna Izba Lekarska dwukrotnie apelowała do Ministerstwa Zdrowia o wdrożenie systemu monitorowania i raportowania liczby zakażeń wśród personelu medycznego w związku z COVID-19 (7). Publikowane za pośrednictwem Polskiej Agencji Prasowej dane dotyczące liczby zakażeń wirusem SARS-CoV-2 wśród personelu medycznego pochodzą z systemu teleinformatycznego (EWP 2.0- Ewidencja Wjazdu do Polski), który służy lekarzom Podstawowej Opieki Zdrowotnej do wystawiania zleceń na badanie w kierunku obecności wirusa. System EWP umożliwia wskazanie zawodu danego pacjenta, w odniesieniu do którego wydawane jest zlecenie na badanie PCR. W odniesieniu do pracowników medycznych wyróżniono następujące kategorie: lekarz, pielęgniarka, ratownik medyczny, inny pracownik medyczny. Dane dotyczące przebiegu zakażenia pochodzą z Krajowego Rejestru Pacjentów z COVID-19 i na ich podstawie udostępniane są informacje o liczbie zgonów wśród personelu medycznego. Aktualne dane z dnia 01.12.2020r. przekazane przez Ministerstwo Zdrowia wskazują, że od początku pandemii zakażeniu uległo łącznie 40669 pielęgniarek, 15720 lekarzy, 2487 ratowników medycznych, 3754 położne, 1253 diagnostów laboratoryjnych, 1636 farmaceutów oraz 20 felczerów. Nie ma jednak dokładnej informacji, czy w wykazie uwzględniono tak- 
of Patients with COVID-19, a total of 43 doctors, 32 nurses, 6 dentists, 3 pharmacists, 2 paramedics, and 2 midwives died by November 30, 2020 (8).

Given the demonstrated significant shortcomings of the adopted reporting methods of the number of SARS-CoV-2 infections amongst healthcare professionals in different countries, it is only possible to approximate the scale of the problem based on the results of studies assessing the frequency of infection in particular centers. Unfortunately, the data were collected according to various protocols, which makes it difficult to compare them at the international level, and at the same time prevents unambiguous conclusions due to the observed significant differentiation in the number of infections in individual professional groups. Hence, it was found that it is worth collecting and organizing the available published data on the epidemiological results documenting the frequency and circumstances of SARS-CoV-2 infections among healthcare workers, which is the purpose of this article.

\section{SARS-CoV-2 INFECTION FREQUENCY AND RISK FACTORS IN THE GROUP OF HEALTH CARE WORKERS}

The available results of meta-analyses on the prevalence of SARS-CoV-2 infection in the social group of healthcare workers indicate that the percentage of infections among healthcare professionals is lower than that reported in previous SARS and MERS epidemics when the number exceeded 20\% (9). By April 2020, Sahu et al. analyzed over 140 reports, of which 11 studies met the criteria necessary to analyze the prevalence of SARS-CoV-2 infection among HCW. The authors estimated that the percentage of infected among 13,199 healthcare professionals in the early phase of the pandemic was $10.1 \%$ (10). Another study by Gómez-Ochoa et al. concerned the scale of infections within the healthcare profession in the USA, Europe, and Asia. It is worth noting that the number of infected workers was assessed both based on a positive PCR test (infection frequency was $11 \%$ ) as well as a serological test (infection frequency was $7 \%$ ). At the same time, the authors of the study indicated that the occupational group most frequently infected were nurses (11).

Nienhaus A. and Hod R. report that by the end of May 2020, 12,393 cases of COVID-19 were registered among healthcare professionals in Germany. This figure, however, applies not only to people infected by the coronavirus but also to those who have seen a significant impact on their health whilst working with the COVID-19 patients. The report was prepared to monitor the occupational illness associated with COVID-19, with the positive RT-PCR test confirming że przypadki z początku epidemii (marzec/kwiecień 2020r.), kiedy to dane o zakażeniach gromadziły powiatowe i wojewódzkie stacje sanitarno-epidemiologiczne. Jeśli zaś chodzi o liczbę zgonów, to wg danych Krajowego Rejestru Pacjentów z COVID-19 do dnia 30.11.2020 zmarło łącznie: 43 lekarzy, 32 pielęgniarki, 6 dentystów, 3 farmaceutów, 2 ratowników medycznych i 2 położne (8).

Wobec wykazanych, istotnych mankamentów przyjętych sposobów raportowania liczby zakażeń wirusem SARS-CoV-2 u personelu medycznego w różnych krajach pozostaje jedynie możliwość przybliżonego oszacowania skali problemu na podstawie wyników badań zajmujących się oceną częstości rozpowszechnienia zakażenia w poszczególnych ośrodkach. Dane zbierane były według różnych protokołów, co znacznie utrudnia porównanie ich na poziomie międzynarodowym, a jednocześnie uniemożliwia jednoznaczne wnioskowanie $\mathrm{z}$ uwagi na zaobserwowane istotne zróżnicowanie częstości zakażeń $\mathrm{w}$ poszczególnych grupach zawodowych. Uznano, że warto zebrać i uporządkować zebrane piśmiennictwo na temat wyników badań epidemiologicznych dokumentujących częstość i okoliczności zakażeń SARS-CoV-2 u pracowników opieki zdrowotnej.

\section{CZESTOŚĆ ZAKAŻEŃ SARS-COV-2 I CZYNNIKI RYZYKA W GRUPIE PRACOWNIKÓW OPIEKI ZDROWOTNEJ}

Dostępne wyniki metaanaliz, dotyczące rozpowszechnienia zakażenia wirusem SARS-CoV-2 w grupie pracowników opieki zdrowotne wskazują, że odsetek zakażeń wśród personelu medycznego jest niższy niż raportowany w trakcie wcześniejszych epidemii SARS oraz MERS, kiedy częstość przekraczała wartość $20 \%$ (9). Sahu i wsp. do kwietnia 2020 r. przeanalizowali ponad 140 doniesień, spośród których 11 badań spełniało kryteria niezbędne do analizy rozpowszechnienia zakażenia SARS-CoV-2 wśród medyków. Autorzy ocenili, że odsetek zakażonych wśród 13199 przedstawicieli zawodów medycznych we wczesnej fazie pandemii wynosił 10,1\% (10). Inna praca, autorstwa Gómez- Ochoa i wsp., dotyczyła skali zakażeń personelu medycznego w USA, Europie i Azji. Warto zaznaczyć, że liczbę zakażonych pracowników oceniano zarówno na podstawie dodatniego wyniku testu PCR (częstość zakażeń wynosiła 11\%), jak i testu serologicznego (częstość zakażeń wynosiła 7\%). Jednocześnie autorzy pracy wskazali, że grupą zawodową najczęściej ulegającą zakażeniu były pielęgniarki (11).

Nienhaus $A$. i $\operatorname{Hod} R$. podają, że do końca maja 2020 roku w Niemczech zarejestrowano 12393 przypadki COVID-19 wśród personelu medycznego. Licz- 
the actual infection only amongst $34.1 \%$ of the registered employees (12). In turn, the report of the Robert Koch Institute of November 18, 2020, indicates that the number of COVID-19 cases with suspected occupational illness concerned 31,241 health care workers. It should be noted that the reported data include only employees of hospitals, outpatient clinics, or dialysis centers and do not include employees of long-term or community care homes (13). The authors themselves point out a certain underestimation of the number of reported infections due to the lack of the need to report people who were asymptomatic or showed mild symptoms whilst infected. They suggest that the actual number of infected workers is at least twice as high as reported (12). The number of workers hospitalized with COVID-19 by November 2020 was 1,079 , and the number of deaths due to the disease was 29 (13). Additionally, it has been documented that the highest risk concerns nurses and doctors $(63.9 \%$ and $15 \%$, respectively) (12). In the opinion of the authors of that report, the highest risk of infection concerned those employees who did not use adequate PPE (personal protective equipment) when in contact with asymptomatic patients. Moreover, in some cases transmission of the virus took place outside the workplace and was related, for example, to spend free time in a region of high epidemic risk (e.g. Italian Alps) (12).

Similar observations apply to healthcare workers in Malaysia, where 224 cases of infections were reported on April 11, 2020, 80\% of which were not related to their work. Also here, the employees caring for the patient became infected most often when without adequate PPE (12). Additionally, the adopted method of data presentation makes it impossible to make appropriate comparisons of the epidemiological situation of SARS-CoV-2 infections in HCW.

The data from Italy is also inconsistent. The Istituto Superiore di Sanità reported the number of infected medical workers as of April 10, 2020. A total of 15,314 people infected were registered, which accounted for $11 \%$ of all infections nationwide (14). On the other hand, Barranco and Ventura indicate a slightly smaller number of infected medics ( $\mathrm{n}=12,680$ as of April 7, $2020)$, they also provide the number of doctors ( $\mathrm{n}=$ $100)$ and nurses $(n=26)$ who died due to COVID-19 (15). It is difficult to conclude whether the observed difference in the number of infected professionals is the result of a three-day difference in reporting, (which would indicate a sharp daily increase in risk,) or whether it rather points at a lack of reliable data.

Some centers are trying to estimate the scale of the SARS-CoV-2 virus infection in healthcare workers based on the results of serological tests. An example of such a study is the Belgian project testing 3,145 employees of four hospitals, where their number ba ta dotyczy jednak nie tylko osób zakażonych koronawirusem, ale również takich, u których zaobserwowano znaczny wpływ na ich zdrowie pracy z osobami zakażonymi. Raport został przygotowywany w celu monitorowania choroby zawodowej związanej z COVID-19, warto dodać, że pozytywny wynik testu RT -PCR potwierdził zakażenie u 34,1\% zarejestrowanych pracowników (12). Z kolei raport Instytutu Roberta Kocha z dnia 18.11.2020 wskazuje, że liczba przypadków COVID-19 z podejrzeniem wystąpienia choroby zawodowej dotyczyła 31241 pracowników ochrony zdrowia. Należy zauważyć, że raportowane dane obejmują jedynie pracowników szpitali, ambulatoriów czy stacji dializ i nie uwzględniają pracowników domów opieki długoterminowej czy środowiskowej (13). Sami autorzy wskazują na pewne niedoszacowanie liczby raportowanych zakażeń, z uwagi na brak konieczności zgłaszania się do rejestru osób przechodzących zakażenie bezobjawowo lub skąpoobjawowo. Sugerują, że rzeczywista liczba zakażonych jest co najmniej dwukrotnie większa niż ta raportowana (12). Liczba pracowników medycznych hospitalizowanych z powodu COVID-19 do listopada 2020 wynosiła 1 079, a liczba zgonów z powodu choroby 29 (13). Dodatkowo udokumentowano, że największe ryzyko ponoszą pielęgniarki oraz lekarze (odpowiednio 63.9\% oraz $15 \%$ zgłoszonych przypadków) (12). W opinii autorów raportu największe ryzyko zakażenia dotyczyło tych pracowników, którzy w kontakcie z pacjentami bezobjawowymi nie stosowali zabezpieczenia w niezbędne środki ochrony osobistej. Ponadto, w niektórych przypadkach do transmisji wirusa dochodziło poza miejscem pracy i miało np. związek ze spędzaniem czasu wolnego w regionie wysokiego ryzyka epidemicznego (Alpy Włoskie) (12).

Podobne obserwacje dotyczą pracowników medycznych w Malezji, gdzie w dniu 11.04.2020 roku odnotowano 224 przypadki zakażeń, spośród których aż $80 \%$ nie miało związku z wykonywaną pracą. Także tutaj najczęściej zakażali się pracownicy sprawujący opiekę nad pacjentem bez stosowania adekwatnych środków ochrony indywidualnej (12). Warto dodać, że przyjęty sposób prezentacji danych uniemożliwia dokonanie stosownych porównań sytuacji epidemiologicznej zakażeń wirusem SARS-CoV-2 u pracowników opieki medycznej.

Równie niespójne są dane pochodzące z Włoch. Istituto Superiore di Sanità podał liczbę zakażonych pracowników medycznych na dzień 10.04.2020r. Łącznie zarejestrowano 15314 zakażonych, co stanowiło $11 \%$ wszystkich zakażeń w całym kraju (14). Z kolei Barranco i Ventura wskazują na nieco mniejszą liczbę zakażonych medyków ( $\mathrm{n}=12680$ stan na dzień 07.04.2020), podają także liczbę zmarłych z powodu COVID-19 lekarzy $(n=100)$ oraz pielęgniarek $(n=26)$ 
of IgG antibodies was determined, indicating infection amongst $14.6 \%$ of the respondents. The highest percentage of positive serological tests concerned the cohorts of nurses, carers, dieticians, occupational therapists, social workers, and psychologists, and amounted to $19.2 \%$. It was smaller in the cohorts of doctors, dentists, physiotherapists, and speech therapists: the positive result was found in $11.8 \%$ of the representatives of these professional groups (16).

Medical workers in Denmark were studied similarly, wherein a cohort study conducted in April 2020 level of antibodies against SARS-CoV-2 virus was determined in 28,792 employees of various health care facilities. A positive serological test result (both IgG and IgM antibodies) was confirmed in 1,163 (4.04\%) employees, with over half of the respondents $(53.5 \%)$ experiencing symptoms such as loss of smell or taste. Among the infected, there were more men, as well as employees who directly cared for patients with COVID-19. Medical students were also tested and they turned out to be the group who most frequently presented the positive $\operatorname{IgG}$ and $\operatorname{IgM}$ antibody results, at the level of $14.97 \%$ (17).

The first attempts to estimate the prevalence of SARS-CoV-2 infection among healthcare professionals took place in China, where a new coronavirus was first identified. By February 2, 2020, the infection was confirmed in 1,716 cases (18). In a single-center study, Ran, Chen et al. documented factors responsible for the increased risk of infection, including prolonged working time (exceeding 10 hours a day) and insufficient hand hygiene. According to the authors, the most common way of infection among hospital staff is the contamination of the facial area by touching it with improperly (insufficiently) disinfected hands. The highest percentage of infected medical workers was reported amongst the staff working in intensive care units (ICUs) and was slightly over 13\%. Nevertheless, it was recognized that the risk is equally high when it comes to staff exposure to air droplets from the patient respiratory tract (18). It was estimated that the percentage of infected medical workers caring for patients with COVID-19 in the early phase of the epidemic in Wuhan was $29 \%$, and the risk was determined by the type of patient contact, the level of exposure to bioaerosol (e.g. during bronchoscopy or intubation), and at the same time, it depended on the individual compliance with health and safety at work procedures (19).

Similar observations were made in a study conducted in the Netherlands. The authors confirmed the lack of a significant level of virus transmission among staff working indirect patient care, provided that PPE was used correctly. The infections were noted most common amongst those caring for asymptomatic patients and thus using inadequate PPE, e.g. surgical masks
(15). Trudno wnioskować, czy zaobserwowana różnica w liczbie zakażonych pracowników medycznych jest efektem trzydniowej różnicy w raportowaniu, co świadczyłoby o gwałtownym dobowym wzroście zagrożenia, czy jest raczej brakiem rzetelnych danych.

Niektóre ośrodki próbują oszacować skalę problemu zakażeń wirusem SARS-CoV-2 u pracowników opieki zdrowotnej na podstawie wyników badań serologicznych. Przykładem takiego badania jest projekt belgijski, wśród 3145 pracowników czterech szpitali ustalono miano przeciwciał klasy IgG wskazujące na przebycie zakażenia u 14,6 \% badanych. Największy odsetek pozytywnych testów serologicznych dotyczył grupy pielęgniarek, opiekunów, dietetyków, terapeutów zajęciowych, pracowników socjalnych i psychologów i wynosił 19,2\%. Mniejszy był w grupie lekarzy, dentystów, fizjoterapeutów i logopedów, wynik pozytywny dotyczył $11,8 \%$ przedstawicieli tej grupy zawodowej (16).

W podobny sposób badano pracowników medycznych w Danii, gdzie w kohortowym badaniu przeprowadzonym w kwietniu 2020r. oznaczono miano przeciwciał przeciwko wirusowi SARS-CoV-2 u 28792 pracowników placówek opieki zdrowotnej. Dodatni wynik testu serologicznego (zarówno przeciwciała klasy IgG, jak i IgM) potwierdzono u 1163 $(4,04 \%)$ pracowników, przy czym ponad połowa badanych $(53,5 \%)$ doświadczyła objawów w postaci utraty węchu czy smaku. Wśród zakażonych częściej znajdowali się mężczyźni, a także pracownicy sprawujący bezpośrednią opiekę nad chorymi z COVID-19. Ocenie poddano także studentów kierunków medycznych i okazało się, że częstość dodatnich wyników testów w kierunku przeciwciał IgG i IgM była u nich największa, kształtowała się na poziomie 14,97\% (17).

Pierwsze próby oszacowania częstości rozpowszechnienia zakażeń wirusem SARS-CoV-2 u personelu medycznego miały miejsce w Chinach, gdzie po raz pierwszy zidentyfikowano nowego koronawirusa. Do dnia 11.02.2020 potwierdzono zakażenie u 1716 pracowników medycznych (18). Ran, Chen i wsp. w badaniu jednoośrodkowym udokumentowali czynniki odpowiedzialne za wzrost ryzyka zakażenia, należały do nich wydłużony czas pracy (przekraczający 10 godzin na dobę) oraz niedostateczna higiena rąk. Zdaniem autorów, najczęstszą drogą zakażenia u personelu szpitalnego jest kontaminacja okolic twarzy poprzez jej dotyk nieprawidłowo (niedostatecznie) zdezynfekowanymi dłońmi. Najwyższy odsetek zakażonych pracowników medycznych dotyczy personelu zatrudnionego w oddziałach intensywnej terapii (OIT) i kształtuje się na poziomie nieco ponad $13 \%$. Niemniej jednak uznaje się, że ryzyko jest równie wysokie $\mathrm{w}$ odniesieniu do narażenia pracownika na aerosol z dróg oddechowych pacjenta (18). Oszaco- 
instead of N95 or FFP2 masks $(20,21)$. Altogether, it was confirmed that $79 \%$ of infected workers had direct contact with COVID-19 patients in the initial phase of the epidemic (i.e. between March 2 and 12, 2020) (22). The cited study shows that the percentage of employees of hospitals in the south of the country infected with SARS-CoV-2 virus was 5\% (96 out of 1,796 examined). It was also found that in the case of every fifth infected worker (19\%), the source of infection were other colleagues who had identified as positive with SARS-CoV-2 14 days before the worker became symptomatic (22).

On the other hand, Long and Nguyen in a cohort study involving over 2 million people in the UK and the US confirmed that the risk of testing positive for SARS-CoV-2 is 12 times higher amongst the workers on the so called 'front line in the fight against COVID-19' (people delivering direct patient care) as compared to the general population. At the same time, they showed that the use of inadequate PPE increases the risk of infection by $31 \%$, and the repeated use of disposable protective equipment increases the risk even by $46 \%$. They also indicated that even with full access to PPE, the potential risk of contamination still exists. The authors estimated the rate of infection in the group of healthcare workers at $10-20 \%$. Female personnel (in both countries), employees with a BMI $>/=30$, and smokers (data for Great Britain) were infected more frequently. The risk of becoming infected was directly related to the place of employment: the greatest risk applied to those employed in hospitals, the adjusted risk ratio was HR $=24.3$ (95\% CI: 21.8327.06). Equally high was the risk for the employees working in nursing homes $(\mathrm{HR}=16.2 ; 13.40-19.70)$, private hospitals $(\mathrm{HR}=11.2 ; 8.44-14.89)$, care homes $(\mathrm{HR}=7.8 ; 5-63,-10.98)$ and in outpatient clinics (HR $=6.9 ; 5.12-9.41)$. The observed difference could be primarily the result of the lack of sufficient and adequate protection for the staff (23). Similarly, Wei, Wang et al. indicated the insufficient availability of PPE as the main factor contributing to virus transmission when it comes to hospital wards (24). In another study conducted in the early stages of the SARS-CoV-2 epidemic in China, Wang et al. pointed out that there is a significant relationship between dealing with an epidemic of a new virus and increased work-related stress as well as decreased sleep quality amongst healthcare workers. In effect, staff experiencing increased stress and declaring lower quality of sleep were infected more often (25).

Research conducted in the United States indicates a varied infection rate among healthcare professionals. Barrett et al. at the turn of March and April 2020, determined the prevalence of SARS-CoV-2 infection among medical staff at $7.3 \%$, while within the gen- wano, że odsetek zakażonych pracowników medycznych sprawujących opiekę nad chorymi z COVID-19 we wczesnej fazie epidemii w Wuhan wynosił $29 \%$ a ryzyko to było uwarunkowane rodzajem kontaktów $\mathrm{z}$ pacjentami, koniecznością pracy w narażeniu na bioaerozol (np. w trakcie bronchoskopii czy intubacji), a jednocześnie zależało od indywidualnego przestrzegania zasad bezpieczeństwa i higieny pracy $\mathrm{z}$ osobami zakażonymi (19).

Podobne obserwacje dotyczyły badania prowadzonego w Holandii. Autorzy potwierdzili brak istotnej transmisji wirusa wśród medyków pracujących w bezpośredniej opiece nad zakażonymi, pod warunkiem prawidłowego stosowania środków ochrony osobistej. Zakażeniom najczęściej ulegał personel medyczny sprawujący opiekę nad chorymi bezobjawowymi, w odniesieniu do których stosowano nieadekwatne środki ochrony indywidualnej np. maski chirurgiczne zamiast masek N95 czy FFP2 $(20,21)$. Mimo to, w początkowej fazie epidemii ( $\mathrm{tj}$. pomiędzy 2. a 12. marca 2020r.) potwierdzono, że 79\% zakażonych pracowników miało bezpośredni kontakt z pacjentami COVID-19 (22). W cytowanej pracy wykazano, że odsetek zakażonych wirusem SARS-CoV-2 pracowników szpitali na południu kraju wynosi 5\% (96 spośród 1796 zbadanych). Ustalono również, że w odniesieniu co do piątego zakażonego pracownika (19\%) źródłem pozostawali współpracownicy, u których zidentyfikowano wirusa SARS-CoV-2 na 14 dni przed wystąpieniem objawów zakażenia u badanego pracownika (22).

Z drugiej strony, Long i Nguyen w badaniu kohortowym dotyczącym ponad 2 miliona osób w Wielkiej Brytanii i USA potwierdzili, że ryzyko wystąpienia pozytywnego wyniku testu w kierunku SARS-CoV-2 jest 12- krotnie większe u osób z tzw. 'pierwszej linii frontu walki z COVID-19' niż u przedstawicieli populacji ogólnej. Jednocześnie wykazali, że stosowanie nieodpowiednich środków ochrony indywidualnej zwiększa ryzyko zakażenia o $31 \%$, a wielokrotne stosowanie jednorazowych ochron zwiększa to ryzyko nawet o $46 \%$. Wskazali także, że nawet przy pełnym dostępie do ochron osobistych potencjalne ryzyko zakażenia nadal istnieje. Autorzy oszacowali częstość zakażeń w grupie pracowników medycznych na poziomie 10-20\%. Częściej zakażeniu ulegał personel żeński (w obydwu krajach), pracownicy z wskaźnikiem należnej masy ciała $\mathrm{BMI}>=30$, a także osoby palące tytoń (dane dla Wielkiej Brytanii). Wielkość ryzyka wystąpienia zakażenia wiązała się z miejscem zatrudnienia, największe ryzyko dotyczyło osób zatrudnionych w placówkach szpitalnych, skorygowany współczynnik ryzyka wynosił HR=24,3 (95\%PU:21,8327,06). Równie wysokie było ryzyko u pracowników zatrudnionych w domach opieki (HR=16,2; 13,40$19,70)$, szpitalach klinicznych $(\mathrm{HR}=11,2 ; 8,44-14,89)$, 
eral population the infection rate was $0.4 \%$. Among healthcare workers, it was mainly nurses who became infected $(11 \%)$, with only $1.8 \%$ of medics in respect. Interestingly, as many as $66 \%$ of the respondents with the identified infection did not experience any symptoms (26). On the other hand, in a single-center study conducted in a hospital in New Jersey which cared for patients with COVID-19, only $0.3 \%$ of healthcare professionals tested positive for PCR. At the same time, specific $\operatorname{IgG}$ antibodies were detected in $9.6 \%$ of the respondents, and the ratio was higher among nurses (9.1\%) than among doctors (7.2\%). It was also shown that workers from African-American backgrounds were infected twice as often as workers who were Caucasian (27).

Yet another study conducted in the United States indicates a relatively high percentage $(13.7 \%)$ of infections among healthcare professionals. The study was conducted in the period from April 20 to June 23, 2020 , on a group of 40,329 volunteers and healthcare workers in the state of New York (USA). The assessment was made based on a serological test and, interestingly, in $5.4 \%$ of seropositive workers, the active infection with SARS-CoV-2 was also confirmed by the PCR test (28). According to the CDC (Centers for Disease Control and Prevention) data, the group of health workers who were most often infected in the USA in the first half of 2020 was the care support staff $(32 \%)$ and the nurses (30\%) (29).

Studies conducted in Central and South America have shown a higher incidence of infections among healthcare professionals than reported in the United States or European countries. An unfavorable situation was reported, for example, in Nicaragua, where the frequency of infections of HCWs was as high as $30.35 \%$, and more than half (55\%) of employees with a positive test result did not experience any symptoms and continued to work with patients despite the infection. Nurses and doctors became infected equally often, then the infected were mostly men and people aged 30-40 years. At the same time, most of the respondents $(80 \%)$ declared using the recommended PPE (30). A similarly high incidence of SARS-CoV-2 infections was reported in Brazil. A single-center study in Sao Paulo (March 21- May 22, 2020) showed that the incidence of infections was at $42.4 \%$. Doctors (55.2\%) were ill more often than nurses (38.4\%). The authors suggest that the actual number of infected may have been even greater, as only the symptomatic workers were tested (31).

On the other hand, a study conducted in one of the hospitals in Madrid confirmed that the number of infected healthcare workers depends on the specialization of a given ward, including the acuity and frequency of the exposure time of the workers. The zespołach opieki domowej $(\mathrm{HR}=7,8 ; 5-63,-10,98)$ oraz w ambulatoriach $(\mathrm{HR}=6,9 ; 5,12-9,41)$. Zaobserwowana różnica mogła być przede wszystkim efektem braku wystarczającego zabezpieczenia pracowników domów opieki we właściwe, adekwatne do zagrożenia środki ochrony osobistej (23). Podobnie Wei, Wang i in. wskazali na niewystarczającą dostępność środków ochrony indywidualnej jako główny czynnik sprzyjający transmisji wirusa $\mathrm{w}$ grupie pracowników oddziałów szpitalnych (24). W innym badaniu przeprowadzonym w początkowej fazie epidemii SARS-CoV-2 w Chinach, Wang i in. wskazali na istotny związek zakażenia nowym koronawirusem ze zwiększonym stresem związanym z pracą oraz jakością snu pracowników medycznych. Osoby odczuwające wzmożony stres oraz deklarujące niższą jakość snu częściej ulegały infekcji (25).

Badania prowadzone w Stanach Zjednoczonych wskazują na zróżnicowaną częstość zakażeń wśród personelu medycznego. Barrett $\mathrm{i}$ in. na przełomie marca i kwietnia 2020 roku określili częstość zakażenia wirusem SARS-CoV-2 wśród personelu medycznego na $7,3 \%$, podczas gdy w populacji ogólnej odsetek zakażeń wynosił 0,4\%. Wśród pracowników medycznych, zakażeniu głównie ulegały pielęgniarki $(11 \%) \mathrm{m}$ a tylko $1,8 \%$ lekarzy zostało zakażonych. Interesujący jest również fakt, że aż $66 \%$ badanych, u których zidentyfikowano zakażenie, nie odczuwała żadnych objawów (26). Z kolei w New Jersey, w jednoośrodkowym badaniu przeprowadzonym w szpitalu sprawującym opiekę nad pacjentami z COVID-19, dodatni wynik testu PCR uzyskano tylko u 0,3\% pracowników medycznych. Jednocześnie swoiste przeciwciała IgG wykryto u 9,6\% badanych, częstość była większa u pielęgniarek (9,1\%) niż u lekarzy (7,2\%). Wykazano także, że zakażeniu dwa razy częściej ulegali pracownicy czarnoskórzy niż rasy białej (27). Kolejne badanie przeprowadzone w Stanach Zjednoczonych wskazuje na dość wysoki odsetek (13,7\%) zakażeń medyków. Badanie przeprowadzono w okresie od 20 kwietnia do 23 czerwca 2020r. w grupie 40329 ochotników, pracowników opieki zdrowotnej w stanie Nowy York (USA). Oceny dokonywano na podstawie testu serologicznego, co ciekawe u 5,4\% seropozytywnych pracowników potwierdzono także aktywne zakażenie SARS-Cov-2 testem PCR (28). Według danych CDC (Centers for Disease Control and Prevention) najczęściej wśród zakażonych pracowników medycznych w USA, w pierwszej połowie 2020 roku, znajdował się personel opiekuńczo-pomocniczy (32\%) oraz pielęgniarki (30\%) (29).

Badania prowadzone w Ameryce Środkowej i Południowej wykazały wyższą częstość zakażeń pracowników medycznych niż w Stanach Zjednoczonych czy krajach europejskich. Niekorzystną sytuację ra- 


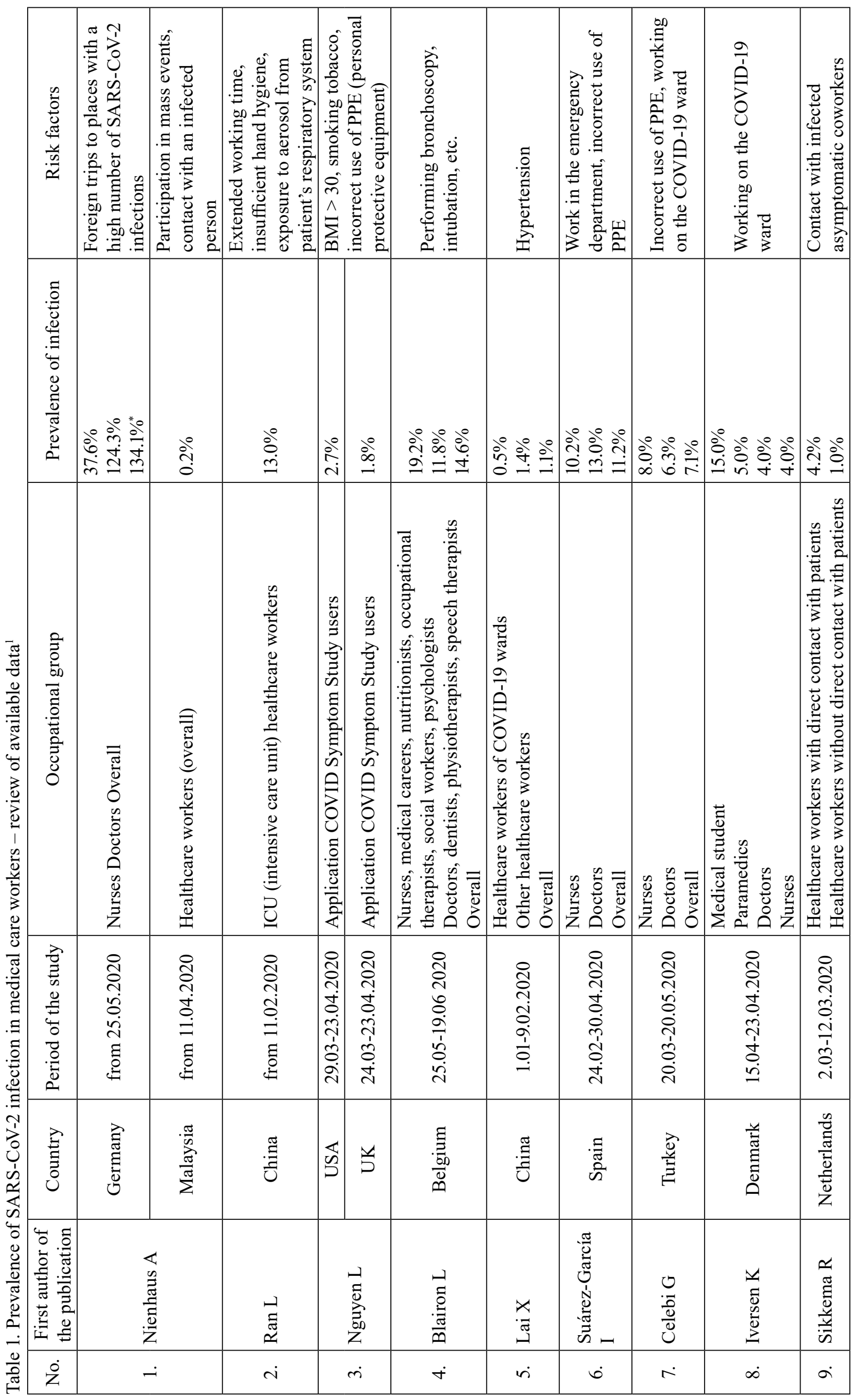




\begin{tabular}{|c|c|c|c|c|c|c|c|}
\hline 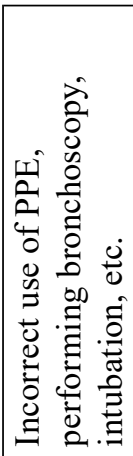 & 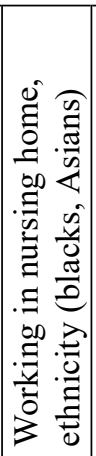 & 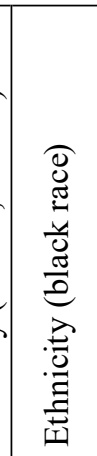 & $\begin{array}{l}\frac{\pi}{\pi} \\
\frac{\pi}{0} \\
0 \\
\dot{z}\end{array}$ & 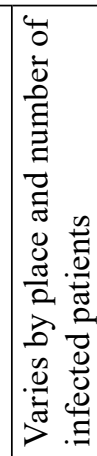 & 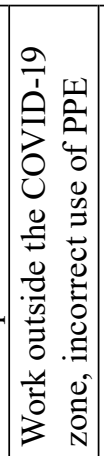 & 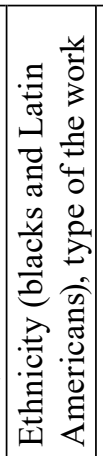 & 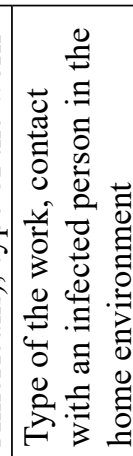 \\
\hline 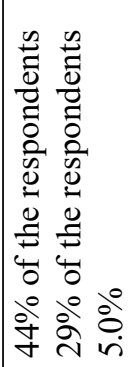 & 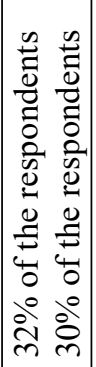 & 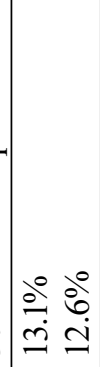 & 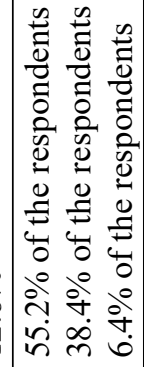 & 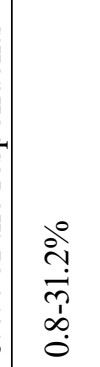 & $\begin{array}{l}\stackrel{0}{0} \\
\stackrel{0}{0}\end{array}$ & $\begin{array}{l}\frac{\partial}{a} \\
\stackrel{\circ}{\circ} \\
\stackrel{0}{N}\end{array}$ & $\stackrel{\circ}{\stackrel{\circ}{\circ}} \stackrel{\partial^{\circ}}{\exists}$ \\
\hline 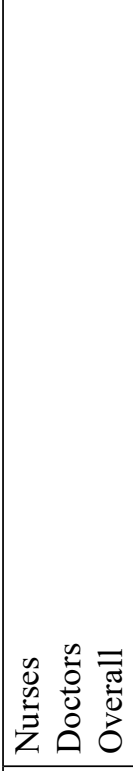 & 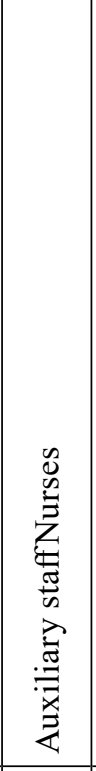 & 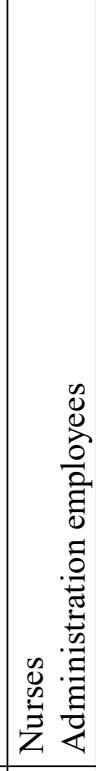 & 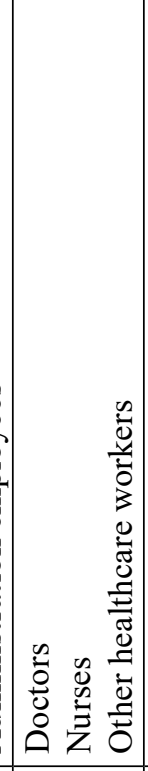 & 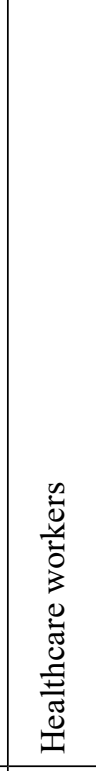 & 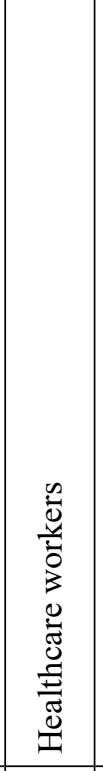 & 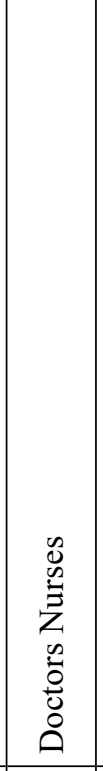 & 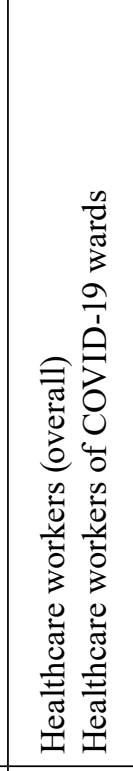 \\
\hline 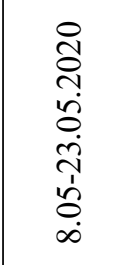 & 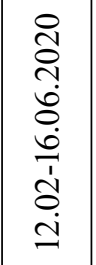 & 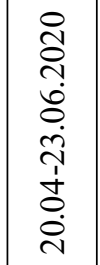 & 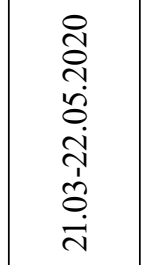 & 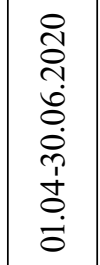 & 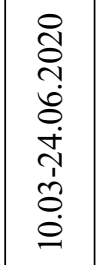 & 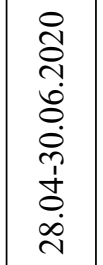 & 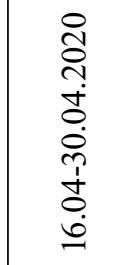 \\
\hline 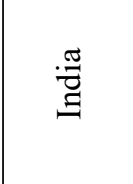 & 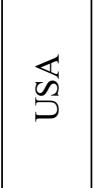 & 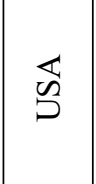 & $\begin{array}{l}\overline{\bar{N}} \\
\overline{\mathscr{N}} \\
\bar{n}\end{array}$ & 㤅 & 离 & 芯 & 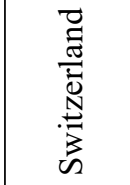 \\
\hline 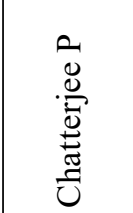 & 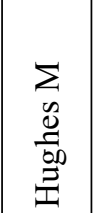 & $\begin{array}{l}\vec{\pi} \\
\frac{\pi}{0} \\
0 \\
0 \\
\Sigma \\
\dot{2}\end{array}$ & 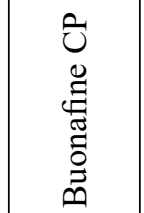 & $\begin{array}{l}I \\
\overrightarrow{0} \\
\frac{\vec{v}}{v} \\
3\end{array}$ & 鹃 & 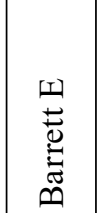 & $\begin{array}{l}:= \\
: 0 \\
0 \\
0 \\
0\end{array}$ \\
\hline$\stackrel{9}{9}$ & $\dot{=}$ & 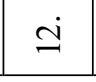 & $\dot{\imath}$ & $\dot{I}$ & 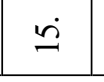 & $\stackrel{\varphi}{9}$ & $\simeq$ \\
\hline
\end{tabular}

portowano np. w Nikaragui, gdzie częstość zakażeń personelu medycznego wynosiła aż 30,35\%, przy czym ponad połowa (55\%) pracowników z pozytywnym wynikiem testu nie odczuwała żadnych objawów i pomimo zakażenia kontynuowała pracę z chorymi. Równie często zakażały się pielęgniarki jak i lekarze, najczęściej mężczyźni, osoby w wieku 30-40 lat, większość badanych $(80 \%)$ deklarowała stosowanie zalecanych środków ochrony indywidualnej (30). Podobnie wysoką częstość zakażeń SARS-CoV-2 odnotowano w Brazylii, badanie jednoośrodkowe w Sao Paulo (21.03- 22.05.2020) dowiodło, że częstość zakażeń wynosiła 42,4\%. Częściej chorowali lekarze (55,2\%) niż pielęgniarki $(38,4 \%)$. Autorzy sugerują, że rzeczywista liczba zakażonych mogła być nawet większa, gdyż testowano jedynie pracowników z objawami (31).

$\mathrm{Z}$ kolei badanie przeprowadzone $\mathrm{w}$ jednym $\mathrm{z}$ madryckich szpitali potwierdziło, że liczba zakażonych pracowników medycznych jest uwarunkowana specjalizacją danego oddziału, włączając intensywność i częstość ekspozycji pracowników na kontakty z chorymi. Największy odsetek zakażonych medyków odnotowano na 'nie covidowym' oddziale ratunkowym $(10,1 \%)$ oraz w oddziale chirurgii $(9,9 \%)$. Potwierdzono także zależność pomiędzy zajmowanym stanowiskiem a liczbą pozytywnych testów w kierunku SARS-CoV-2, najczęściej zakażeniom ulegały pielęgniarki przełożone i koordynatorki (37,5\%), a także ordynatorzy oddziałów (23,1\%). Mniejsze odsetki dotyczyły szeregowych pielęgniarek $(10,2 \%)$ oraz lekarzy $(13 \%)$. Wykazano, że zakażeniu wirusem SARS-CoV-2 uległo ostatecznie 11\% wszystkich pracowników szpitala, co i tak było wartością dwa razy mniejszą niż wartość oszacowana w tamtym okresie dla całego kraju (32).

Nieco odmiennie prezentuje się sytuacja w Turcji. $\mathrm{Na}$ podstawie wyników badania jednoośrodkowego ustalono, że największe ryzyko zakażenia wirusem SARS-CoV-2 dotyczyło pracowników zatrudnionych w oddziałach przeznaczonych dla chorych na COVID-19. Obliczono, że odsetek dodatnich wyników testu RT-PCR u pracowników sprawujących opiekę nad tymi pacjentami wynosił $8,3 \%$ i był ponad dwukrotnie większy niż u pracowników zatrudnionych w strefie bez pacjentów z COVID-19 (3,4\%). Największy odsetek zakażonych pracowników medycznych dotyczył pielęgniarek (8\%) przy wartości średniej 7,15\% dla całej populacji osób zatrudnionych w szpitalu. Jednocześnie, dochodzenie epidemiologiczne wykazało, że do transmisji wirusa dochodziło głównie w pokojach socjalnych w trakcie spożywania przez personel wspólnych posiłków, podczas których nie stosowano indywidualnych zabezpieczeń. Zespół ds. zakażeń zmienił wówczas wewnętrzne zasady organizacji odpoczynku w pracy i zalecił konieczność noszenia maseczek przez cały czas przebywania na terenie placów- 
highest percentage of the infected staff was recorded within the 'non-covid' emergency department (10.1\%) and in the surgical department $(9.9 \%)$. The correlation between the position held and the number of positive tests for SARS-CoV-2 was also confirmed, with the ward sisters and nurses in charge (37.5\%), as well as ward consultants $(23.1 \%)$, becoming infected most often. Staff nurses $(10.2 \%)$ and doctors $(13 \%)$ indicated a lower infection rate as a group. All in all the study has shown that on average $11 \%$ of all hospital workers were infected with SARS-CoV-2 virus, which was a value two times lower than the number estimated at that time for the entire country (32).

The situation in Turkey turned out to be somewhat different. Based on the results of a single-center study, it was established that the highest risk of infection with the SARS-CoV-2 virus on the wards dedicated to COVID-19 patients. It was calculated that the percentage of positive RT-PCR test results among the employees caring for these patients was $8.3 \%$ and was over twice as high as among the employees working in the departments without COVID-19 patients (3.4\%). The highest rate of infected healthcare workers was among nurses $(8 \%)$ with an average value of $7.15 \%$ for the entire population of people employed in a hospital. At the same time, an epidemiological investigation found that transmission of the virus mainly occurred in staff rooms at the time when workers were eating or resting, and where no individual safeguards were applied. At that time, the infection prevention team changed the internal rules for organizing rest at work and recommended wearing masks at all times while on the premises, and ordered eating separately. Additional training on the proper use of PPE was also organized. The results of the evaluation showed that implementing these simple recommendations improved the situation in the hospital - only one employee was infected. Unfortunately, we do not know if monitoring of the described situation still takes place. The study also confirmed that the important factors increasing the risk of infection amongst healthcare professionals include potential exposure in the home environment (outside of the workplace), inappropriate use of PPE whilst taking care of patients with COVID-19, staff interaction for more than 15 minutes whilst not wearing a mask, eating meals together within $1 \mathrm{~m}$, or not keeping a safe distance from other team members while working (33).

Last, the situation in India was slightly different. Within the group of 21,402 healthcare staff in the period from May 8 to 23, 2020 the infection with SARSCoV-2 virus was confirmed in $5 \%$ of respondents (1,073 PCR confirmations). Based on the interviews collected from 378 infected, it was established that the nurses (44\%) and doctors (29\%) were most affected (34). ki, a także nakazano spożywanie posiłków oddzielnie. Zorganizowano również dodatkowe szkolenie na temat właściwego stosowania środków ochrony indywidualnej. Wyniki ewaluacji wykazały, że wdrożenie tych prostych zaleceń poprawiło sytuację w szpitalu - zakażeniu uległ tylko jeden pracownik. Niestety nie mamy wiedzy na temat, czy kontynuowane są działania monitoringowe dla opisanej sytuacji. W trakcie badania potwierdzono również, że wśród istotnych czynników zwiększających ryzyko infekcji u pracowników medycznych jest potencjalne narażenie w środowisku domowym (poza miejscem pracy), a także niewłaściwe stosowanie PPE (Personal Protective Equipment) w opiece nad pacjentami z COVID-19, wspólne przebywanie pracowników bez masek powyżej 15 minut, wspólne spożywanie posiłków w odległości do $1 \mathrm{~m}$, czy brak zachowania dystansu względem członków zespołu podczas wykonywania pracy (33).

Nieco inaczej wyglądała sytuacja w Indiach. W grupie 21402 pracowników medycznych w okresie od 8 do 23 maja 2020r. potwierdzono zakażenie wirusem SARS-CoV-2 u 5\% badanych (1 073 potwierdzeń testem PCR). Na podstawie wywiadów zebranych od 378 zakażonych udało się ustalić, że najczęściej zakażeniu ulegały pielęgniarki (44\%) oraz lekarze $(29 \%$ badanych) (34). W tabeli poniżej zamieszczono wykaz cytowanych w pracy publikacji dotyczących częstości zakażonych pracowników medycznych.

\section{WNIOSKI}

Przegląd dostępnego piśmiennictwa wskazuje, że rozpowszechnienie zakażenia wirusem SARS-CoV-2 wśród pracowników medycznych w poszczególnych krajach jest bardzo zróżnicowane. Wydaje się, że wśród głównych uwarunkowań obserwowanych rozbieżności znajdują się m.in. wiedza samych pracowników na temat zagrożenia i kwestie organizacji pracy z potencjalnie zakażonymi pacjentami czy współpracownikami. Ważną rolę odgrywa tu dostępność i prawidłowe użytkowanie środków ochrony indywidualnej, a jednocześnie częstość i długość trwania ekspozycji na materiał potencjalnie zakaźny w trakcie wykonywania obowiązków zawodowych.

Wspomniany na wstępie brak jednolitego, przejrzystego systemu raportowania zakażeń u pracowników medycznych w naszym kraju sprawia, że wiarygodna ocena sytuacji epidemiologicznej w tym zakresie nie jest możliwa. Warto więc rozważyć wdrożenie obowiązku ewidencjonowania danych pacjentów zakażonych, identyfikujących także wykonywany zawód, a następnie utworzenie centralnego rejestru umożliwiającego monitorowanie rozpowszechnienia zakażenia wirusem SARS-CoV-2 w grupach zawodowych. Proponowane rozwiązanie ułatwi jednoznaczną oce- 
The table below lists the publications cited in this paper regarding the number of infected medical workers.

\section{CONCLUSIONS}

A review of the available literature shows that the prevalence of SARS-CoV-2 infection among medical workers varies between countries. It seems that the main determinants of the observed discrepancies include, among others, knowledge of the employees themselves about the risk and issues around organizing work with potentially infected patients and/or colleagues. The availability and proper use of adequate PPE play a huge role here, as well as the frequency and duration of the exposure to potentially infectious material during the performance of professional duties.

The lack of a uniform, transparent infection reporting system for healthcare workers in our country, mentioned at the beginning, makes it impossible to reliably assess the epidemiological situation in this area. Therefore, it is worth considering the implementation of the obligatory record making of the data of the infected patients, altogether with their profession, and then the creation of a central register enabling the monitoring of SARS-CoV-2 infections within the professional groups. The proposed solution will facilitate an unequivocal assessment of the epidemiological situation and will allow for the development of effective procedures ensuring the safety of employees caring for COVID-19 patients.

\section{REFERENCES}

1. Nguyen LH, Drew DA, Joshi AD, Guo C-G, Ma W, Mehta RS, i in. Risk of COVID-19 among front-line health-care workers and the general community: a prospective cohort study. Lancet Public Health 2020; 5(9): 475-483.

2. WHO. Situation Report Coronavirus Disease 2019 (Covid-19) Situation Report-82. Dostęp online: https://www.who.int/docs/default-source/ coronaviruse/situation-reports/20200411-sitrep82-covid-19.pdf? sfvrsn=74a5d15_2.

3. ECDC. Risk factors and risk groups. Dostęp online: https://www.ecdc.europa.eu/en/covid-19/ latest-evidence/epidemiology.

4. ICN. ICN calls for data on healthcare worker infection rates and deaths. Dostęp online: https:// www.icn.ch/news/icn-calls-data-healthcareworker-infection-rates-and-deaths.

5. WHO. WHO calls for healthy, safe and decent working conditions for all health workers, amidst COVID-19 pandemic. Dostęp online: https://www. who.int/news/item/28-04-2020-who-calls-for- nę sytuacji epidemiologicznej i pozwoli wypracować efektywne procedury zapewniające bezpieczeństwo pracowników sprawujących opiekę nad chorymi na COVID-19.

healthy-safe-and-decent-working-conditions-forall-health-workers-amidst-covid-19-pandemic.

6. PAHO. Epidemiological Update: Coronavirus disease (COVID-19) - 9 November 2020. Dostęp online: https://www.paho.org/en/documents/ epidemiological-update-coronavirus-diseasecovid-19-9-november-2020.

7. Naczelna Izba Lekarska. Ponowny apel o raportowanie o zakażeniach i zgonach wśród personelu medycznego w zw. z Covid-19. Dostęp online: https://nil.org.pl/aktualnosci/5183ponowny-apel-o-raportowanie-zakazen-i-zgonowwsrod-personelu-medycznego-w-zw-z-covid-19.

8. Onet.pl. Ile pielęgniarek i lekarzy zmarło w Polsce przez COVID-19? Są dane ministerstwa. Dostęp online: https://www.onet.pl/styl-zycia/onetkobieta/ koronawirus-ile-pielegniarek-i-lekarzy-zmarlo-wpolsce-przez-covid-19/pskx5m6,2b83378a.

9. Labetoulle R, Detoc M, Gagnaire J, Berthelot P, Pelissier C, Fontana L, Botelho-Nevers E, GagneuxBrunon A. COVID-19 in health-care workers: lessons from SARS and MERS epidemics and perspectives for chemoprophylaxis and vaccines. Expert Rev Vaccines. 2020;19(10):937-947.

10. Sahu AK, Amrithanand VT, Mathew R, Aggarwal P, Nayer J, Bhoi S. COVID-19 in health care workers - A systematic review and meta-analysis. Am J Emerg Med. 2020;3(9):1727-1731.

11. Gómez-Ochoa SA, Franco OH, Rojas LZ, Raguindin PF, Roa-Díaz ZM, Wyssmann BM, Guevara SLR, Echeverría LE, Glisic M, Muka T. COVID-19 in Health-Care Workers: A Living Systematic Review and Meta-Analysis of Prevalence, Risk Factors, Clinical Characteristics, and Outcomes. Am J Epidemiol. 2021;190(1):161175.

12. Nienhaus A, Hod R. COVID-19 among health workers in Germany and Malaysia. Int $\mathrm{J}$ environ res public health 2020; 17(13), 4881.

13. Robert Koch Institute. COVID-19 Situation Report 6.12.2020. Dostęp online: https://www.rki.de/ DE/Content/InfAZ/N/Neuartiges_Coronavirus/ Situationsberichte/Dez_2020/2020-12-06-en. pdf?_blob=publicationFile.

14. Istituto Superiore di Sanità. Integrated surveillance of COVID-19 in Italy. Dostęp online: https:// www. epicentro.iss.it/en/coronavirus/bollettino/ Infografica_10aprile\%20ENG.pdf.

15. Barranco R, Ventura F. Covid-19 and infection in health-care workers: An emerging problem. Med Leg J. 2020; 88(2): 65-66. 
16. Blairon L, Mokrane S, Wilmet A, Dessilly G, Kabamba-Mukadi B, Beukinga I, Tré-Hardy M. Large-scale, molecular and serological SARSCoV-2 screening of healthcare workers in a 4-site public hospital in Belgium after COVID-19 outbreak. J Infect. 2020; 82(1):159-98.

17. Iversen $\mathrm{K}$, Bundgaard $\mathrm{H}$, Hasselbalch $\mathrm{RB}$, Kristensen JH, Nielsen PB, Pries-Heje M, Knudsen AD, Christensen CE, Fogh K, Norsk JB, Andersen O, Fischer TK, Jensen CAJ, Larsen M, Torp-Pedersen C, Rungby J, Ditlev SB, Hageman I, Møgelvang R, Hother CE, Gybel-Brask M, Sørensen E, Harritshøj L, Folke F, Sten C, Benfield T, Nielsen SD, Ullum H. Risk of COVID-19 in health-care workers in Denmark: an observational cohort study. Lancet Infect Dis. 2020; 20(12):14011408.

18. Ran L, Chen X, Wang Y, Wu W, Zhang L, Tan X. Risk Factors of Healthcare Workers With Coronavirus Disease 2019: A Retrospective Cohort Study in a Designated Hospital of Wuhan in China. Clin Infect Dis. 2020; 71(16): 2218-2221.

19. Bielicki JA, Duval X, Gobat N, Goossens H, Koopmans M, Tacconelli E, van der Werf S. Monitoring approaches for health-care workers during the COVID-19 pandemic. Lancet Infect Dis. 2020; 20(10): 261-267.

20. Kluytmans-van den Bergh MFQ, Buiting AGM, Pas SD, Bentvelsen RG, van den Bijllaardt W, van Oudheusden AJG, van Rijen MML, Verweij JJ, Koopmans MPG, Kluytmans JAJW. Prevalence and Clinical Presentation of Health Care Workers With Symptoms of Coronavirus Disease 2019 in 2 Dutch Hospitals During an Early Phase of the Pandemic. JAMA Netw Open. 2020; 3(5): 209673.

21. Lai X, Wang M, Qin C, Tan L, Ran L, Chen D, Zhang H, Shang K, Xia C, Wang S, Xu S, Wang W. Coronavirus Disease 2019 (COVID-2019) Infection Among Health Care Workers and Implications for Prevention Measures in a Tertiary Hospital in Wuhan, China. JAMA Netw Open. 2020; 3(5): 209666.

22. Sikkema RS, Pas SD, Nieuwenhuijse DF, O'Toole Á, Verweij J, van der Linden A, Chestakova I, Schapendonk C, Pronk M, Lexmond P, Bestebroer T, Overmars RJ, van Nieuwkoop $S$, van den Bijllaardt W, Bentvelsen RG, van Rijen MML, Buiting AGM, van Oudheusden AJG, Diederen BM, Bergmans AMC, van der Eijk A, Molenkamp R, Rambaut A, Timen A, Kluytmans JAJW, Oude Munnink BB, Kluytmans van den Bergh MFQ, Koopmans MPG. COVID-19 in healthcare workers in three hospitals in the south of the Netherlands: a cross-sectional study. Lancet Infect Dis. 2020; 20(11):1273-1280.

23. Nguyen LH, Drew DA, Joshi AD, Guo C-G, Ma W, Mehta RS, $i$ in. Risk of COVID-19 among front-line health-care workers and the general community: a prospective cohort study. Lancet Public Health 2020; 5(9): 475-483.

24. Wei XS, Wang XR, Zhang JC, Yang WB, Ma WL, Yang BH, Jiang NC, Gao ZC, Shi HZ, Zhou Q. A cluster of health care workers with COVID-19 pneumonia caused by SARS-CoV-2. J Microbiol Immunol Infect. 2020; S1684-1182(20)30107-9.

25. Wang $X$, Jiang $X$, Huang Q, Wang $H$, Gurarie D, Ndeffo-Mbah M, Fan F, Fu P, Horn M A, Mondal A, King C, Xu S, Zhao H, Bai Y. Risk factors of SARS-CoV-2 infection in healthcare workers: a retrospective study of a nosocomial outbreak. Sleep Med X. 2020; 2:100028.

26. BarrettES, Horton DB, Roy J, Gennaro ML, Brooks A, Tischfield J, Greenberg P, Andrews T, Jagpal S, Reilly N, Blaser MJ, Carson JL, Panettieri RA Jr. Prevalence of SARS-CoV-2 infection in previously undiagnosed health care workers at the onset of the U.S. COVID-19 epidemic. medRxiv [(Preprint]). BMC Infect Dis. 2020 Nov 16;20(1):853.

27. Barrett ES, Horton DB, Roy J, Xia W, Greenberg $\mathrm{P}$, Andrews T, Gennaro ML, Parmar V, Russell WD, Reilly N, Uprety P, Gantner JJ, Stockman L, Trooskin SZ, Blaser MJ, Carson JL, Panettieri RA Jr. Risk Factors for Severe Acute Respiratory Syndrome Coronavirus 2 Infection in Hospital Workers: Results From a Screening Study in New Jersey, United States in Spring 2020. Open Forum Infect Dis. 2020 Oct 31;7(12):ofaa534.

28. Moscola J, Sembajwe G, Jarrett M, Farber B, Chang T, McGinn T, Davidson KW; Northwell Health COVID-19 Research Consortium. Prevalence of SARS-CoV-2 Antibodies in Health Care Personnel in the New York City Area. JAMA. 2020;324(9):893-895.

29. Hughes MM, Groenewold MR, Lessem SE, Xu K, Ussery EN, Wiegand RE, Qin X, Do T, Thomas D, Tsai S, Davidson A, Latash J, Eckel S, Collins J, Ojo M, McHugh L, Li W, Chen J, Chan J, Wortham JM, Reagan-Steiner S, Lee JT, Reddy SC, Kuhar DT, Burrer SL, Stuckey MJ. Update: Characteristics of Health Care Personnel with COVID-19 - United States, February 12-July 16, 2020. MMWR Morb Mortal Wkly Rep. 2020;69(38):1364-1368.

30. Huete-Pérez JA, Cabezas-Robelo C, Páiz-Medina L, Hernández-Álvarez CA, Quant-Durán C, McKerrow JH. First report on prevalence of SARS$\mathrm{CoV}-2$ infection among health-care workers in Nicaragua. PLoS One. 2021 Jan 27;16(1):e0246084.

31. Buonafine CP, Paiatto BNM, Leal FB, de Matos SF, de Morais CO, Guerra GG, Martuchelli MVV, Oliveira DBL, Durigon EL, Soares CP, Candido ED, Telezynski BL, Sáfadi MAP, Almeida FJ. High prevalence of SARS-CoV-2 infection among symptomatic healthcare workers in a large 
university tertiary hospital in São Paulo, Brazil. BMC Infect Dis. 2020 Dec 2;20(1):917.

32. Suárez-García I, Martínez de Aramayona López MJ, Sáez Vicente A, Lobo Abascal P. SARS-CoV-2 infection among healthcare workers in a hospital in Madrid, Spain. J Hosp Infect. 2020;106(2): 357363.

33. Çelebi G, Pişkin N, Çelik Bekleviç A, Altunay Y, Salc1 Keleş A, Tüz MA, Altınsoy B, Hacıseyitoğlu D. Specific risk factors for SARSCoV-2 transmission among health care workers in a university hospital. Am J Infect Control. 2020; 48(10): 1225-1230.

34. Chatterjee P, Anand T, Singh KJ, Rasaily R, Singh R, Das S, Singh H, Praharaj I, Gangakhedkar RR, Bhargava B, Panda S. Healthcare workers \& SARS-CoV-2 infection in India: A case-control investigation in the time of COVID-19. Indian J Med Res. 2020; 151(5):459-467.
Received: 25.01.2021 r.

Accepted for publication: $26.02 .2021 \mathrm{r}$.

Otrzymano: 25.01.2021 r.

Zaakceptowano do publikacji: $26.02 .2021 \mathrm{r}$.

\section{Address for correspondence:}

Adres do korespondencji:

Małgorzata Kowalska

Katedra i Zakład Epidemiologii

Wydział Nauk Medycznych w Katowicach

Śląski Uniwersytet Medyczny

40-752 Katowice

Ul. Medyków 18

Adres e-mail: mkowalska@sum.edu.pl

Tel. 322088543 